\title{
The Effects of COVID-19 on the Digital Transformation of the Hungarian Banking Sector
}

\author{
TIBOR TÓTH* \\ *Corvinus University of Budapest, Doctoral School of Business and Management; \\ tibor.toth@stud.uni-corvinus.hu
}

DOI: 10.14267/978-963-503-867-1_06

\begin{abstract}
When choosing the topic, I tried to focus on dealing with such a current and ongoing event, we still don't see the result, and I just find where it develops in three, five, or ten years. Digitization affects all segments and industries to varying degrees, and its impact can be widely demonstrated. Besides, the precarious economic situation resulting from the COVID-19 epidemic further complicates the situation. I found the topic relevant because I am dealing with a phenomenon, a dilemma that directly or indirectly affects everyone and can be useful to a wider audience. During the dissertation, I try to answer the following questions: How does COVID-19 affect the process of digital transformation in the Hungarian banking sector? And how does this affect the collaboration strategies of banks and FinTech companies? In my work, I rely mainly on previous publications and articles by international, prominent researchers. Also, I conducted interviews with Hungarian experts who are currently actively working for Hungarian banks. During the selection of the interviewees, I followed the concept of asking the employees of different financial institutions working at different levels for the most comprehensive picture. In terms of methodology, in addition to processing the interviews and evaluating the literature, I tried to collect and analyze surveys and public data from various commercial banks, regulatory bodies, and major consulting firms. In this article, I have collected trends that have influenced the current state of the banking sector and present the operating environment. In addition to the positive and negative factors influencing the relationship between domestic commercial banks and FinTech companies, I outline a possible scenario for a future digitization strategy for the banking sector. This exploratory research aims to examine the situation and to identify the most important variables and correlations.
\end{abstract}

Keywords: Banking industry, FinTech, digital transformation, COVID-19

Funding: The present publication is the outcome of the project „From Talent to Young Researcher project aimed at activities supporting the research career model in higher education,"identifier EFOP3.6.3-VEKOP-16-2017-00007 co-supported by the European Union, Hungary, and the European Social Fund. 


\section{Introduction}

The main theme for 2020 and probably the coming years is the COVID-19 epidemic. The sudden economic turmoil caused by the epidemic is not only devastating but also has side effects, as human endeavor has triggered demand and supply shocks in almost every area (El-Erian, 2020). The subject of my study is the financial sector is no exception. The main research question is how does COVID-19 affect the process of digital transformation in the Hungarian banking sector? How does this affect the collaboration strategies of banks and FinTech companies?

When choosing the topic, I tried to focus on dealing with such a current and ongoing event, we still do not see the result and we can only guess where it will develop in three, five, or ten years. Digitization affects all segments and industries to varying degrees, and its impact can be widely and demonstrated. Besides, I found the topic relevant because I am dealing with a phenomenon, a dilemma that directly or indirectly affects everyone and can be useful to a wider audience. The situation is further complicated by the precarious economic situation resulting from the COVID-19 pandemic. The situation is new to everyone because since we can talk about digitization, we have not seen a crisis that was not caused by the money market. As the financial institution sector has a history of several centuries and we are talking about a traditional industry, I find it extremely interesting to study how participants are coping with changing market conditions and unprecedented challenges due to digitalization.

In this article, I have collected trends that have influenced the current state of the banking sector and present the operating environment. In addition to the positive and negative factors influencing the relationship between domestic commercial banks and FinTech companies, I outline a possible scenario for a future digitization strategy for the banking sector. The aim of this exploratory research is to examine the situation and to identify the most important variables and correlations.

\section{Theoretical background}

The number of articles published on the topic of digital transformation, which forms the basis of my research, has grown exponentially over the past decade, reflecting the role of digitization in the 21st century. The appearance of FinTech has created further divisions in the subject, with better quality and more comprehensive research articles on digital banking strategies and the relationship between banks and FinTech. Mills and McCarthy (2017) have identified four different strategies that traditional banks can choose to compete or collaborate with online rivals (in some cases, they implement both at the same 
time). These are arm's-length strategy, partnership, build or buy strategy, long-tail strategy. The choice of strategy depends on two factors, one is how much time and money the bank invests in entering the new market, the other in the new digital activity, and the level of integration between operations.

The categorization based on the global survey, which identified four different cooperation models between FinTech companies and banks, is more practice-oriented and much more useful in the analysis of the Hungarian market. During my research, I examine market tendencies along with this categorization, which differentiates in-house development and acquisition, strategic cooperation agreement, and capital investment (Kerényi et al., 2018). Furthermore, for a comprehensive analysis of the topic, it is essential to analyze the audited IFRS and annual reports of commercial banks with a significant role in the market, to examine the studies and analyses carried out by the various regulatory bodies.

Although we are talking about a one-year phenomenon in the case of the COVID-19 epidemic, thousands of scientific articles have already been published, a phenomenon that is of concern to all scientific life. Overall, it can be stated that a number of high-quality publications have been published on the topic, although due to the size of the market, only a few deals specifically with Hungarian market conditions.

\section{Methods}

In my research, I focused on the qualitative research methodology. In addition to the literature review, I also examined the statements of public conferences and round table discussions between professionally credible managers and leaders. In order to get to know the practical operation of the theoretical suggestions, I conducted in-depth interviews with people who are themselves active participants in the processes.

In selecting the interviewees, I followed the concept of asking the staff of different financial institutions working at different levels for the most comprehensive picture. As a result, there were a deputy CEO, a senior manager, an IT developer, and a middleware engineer among the respondents. The questions can be grouped into three major topics. The first issue concerns the current performance of the banking sector and, among other things, I was curious about the differences between the banking markets of Hungary and the surrounding countries in terms of digital development, and what will be the biggest challenges for market participants in the next period. In the following topics, the possibilities and difficulties of cooperating with FinTech startups were highlighted. At the end of the interviews, I addressed the challenges of the digital switchover, including the 
returns, the evaluation of the efforts made so far, and the positive and negative effects of digitalization.

During the data collection, I tried to focus not only on financial indicators but also to derive the factors and recent events that have greatly influenced the development of the segment. In addition to industry specifics, I also analyzed the macro environment. For this, I used not only the IFRS and annual reports of various commercial banks but also interviews and statements from professionals. At this point in the research, I considered two aspects important, on the one hand, credibility (reliable source) and on the other hand diversity. In the process, I made sure that the sources included different interest groups and different perspectives. As a result, the resources include the experiences of market participants and consumers, the views of regulators, various consulting and analysis firms (as external stakeholders), and the views of the scientific community.

\section{Results}

The current crisis cannot be compared to the 2008 financial crisis. On the one hand, as I have already mentioned, the root cause is different, and on the other hand, we do not see the exact end of the current crisis yet. Of course, a parallel can be found between the COVID-19 crisis and the events after 2008. Even in 2008, during the previous recession, many assumed that the effects would be largely localized, at that time in the US and now in China (Elliott, 2020). It quickly became clear that we were wrong, as we were in 2008.

During the first wave, most analysts envisioned a rapid crisis with a V-shaped recovery, but now more and more people are talking about a prolonged correction period. From over 110 CEOs surveyed by The Conference Board, 55\% predicted a U-shaped recovery in Europe over 1-2 years (Ghosh, 2020). According to Baker and Judge (2020), the FinTech world may play a greater role in the global financial intermediation system than before. This is because it is easier to finance the population as well as the micro and small enterprises in the economy.

\section{Banking sector overview}

The general international panic that characterized the first quarter of 2020 caused a $74 \%$ decline in the after-tax profit of the credit institution sector compared to 2019 Q1 otherwise. The deterioration in profitability is mainly related to impairment and provisioning. In the first three quarters of 2020, the Hungarian banking sector achieved a consolidated after-tax profit of HUF 305 billion, which is $54 \%$ of the previous year's figure. Although the ratio of non-performing loans to the moratorium on repayment has always 
decreased, banks have already recorded a net impairment of HUF 294 billion, and the whole thing would be understood at roughly normal levels. The net impairment of the domestic consolidated banking system in the first half of the year is high internationally (MNB, 2020, November). After a stuck period in corporate lending in the first quarter, lending activity is recovering rapidly. The central bank and government loan and guarantee programs support the expansion of lending. In terms of capital position and liquidity, the Hungarian banking system is resistant to even severe economic stress.

The general view of those I interviewed is that the year 2021 will be as difficult and challenging as 2020, yet they are optimistic mainly as far as the processes of digitization are concerned. One of the main drivers of this is the significant increase in consumer acceptance and use of digital financial solutions. As a result of restrictions and lockdowns, cash flow and bank branch visits decreased significantly, and interest in online banking increased. This is supported by a survey conducted by the central bank in the summer of 2020, which shows that almost one-fifth of the online active population is more likely to manage their finances online as a result of the epidemic. Due to these changes, online banking is already the second most widely conducted online activity, preceded only by the use of social media, according to the survey (Danóczy \& Sajtos, 2020).

At the end of 2019 and the beginning of 2020, the central bank assessed the level and preparedness of domestic incumbent banks in two stages. The results of the survey show that although the banking system is aware of the opportunities and challenges of the digital transformation, there is still significant potential for further development. Survey participants the digital development of the banking system is assessed as average overall. The digitalization of internal operations shows a similarly more favorable picture in the sector, while the digitalization of relations with external aspects (digital accessibility of products, developments aimed at digitizing customer relations) needs to be improved on several points. In terms of internal operations, the digitalization of work processes and the digital readiness of the workforce performed best in the case of the domestic banking system (MNB, 2020, April). Compared to the assessment of domestic bank managers, Deloitte's global survey shows a more pessimistic picture of the digital maturity of the sector. During the survey, the key factors were functionality and customer preferences. Based on these, the Hungarian sector belongs to the end of the digital adopter's group. In the Central and Eastern European region, Poland stands out as a digital champion and the Czech Republic as a smart follower. The Hungarian banking sector is broadly at the Croatian and Slovenian levels in terms of the level of services available on digital channels (Deloitte, 2018). 


\section{The position of Fin Tech companies}

One of the key factors influencing the digital maturity of the credit institution sector is the degree of cooperation with FinTech companies. In addition to the incumbents who dominate the vast majority of the domestic financial market, there are currently more than 110 companies registered in Hungary that conduct FinTech business. The domestic FinTech sector has been characterized by dynamic expansion in recent years, which, in addition to the increase in the number of customers, shows a significant increase in the number of employees and sales revenue. Among Hungarian-owned FinTech companies (about three-quarters of the sector), micro and small enterprises dominate, while in the case of foreign-owned firms, the proportion of smaller and larger firms can be considered relatively balanced. Regardless of the ownership structure, the Hungarian FinTech sector is characterized by B2B services, the share of B2C services is less than 10 percent in terms of company number, and they are typically aimed at providing payment services, investments, financing, and insurance (MNB, 2020, April). As the chart shows, only $20 \%$ of companies deal with the service that affects the largest number of retail customers, payment services.

Figure 1: Distribution of the number of FinTech companies per scope of services

\section{Distribution of the number of FinTech companies according to the scope of services}

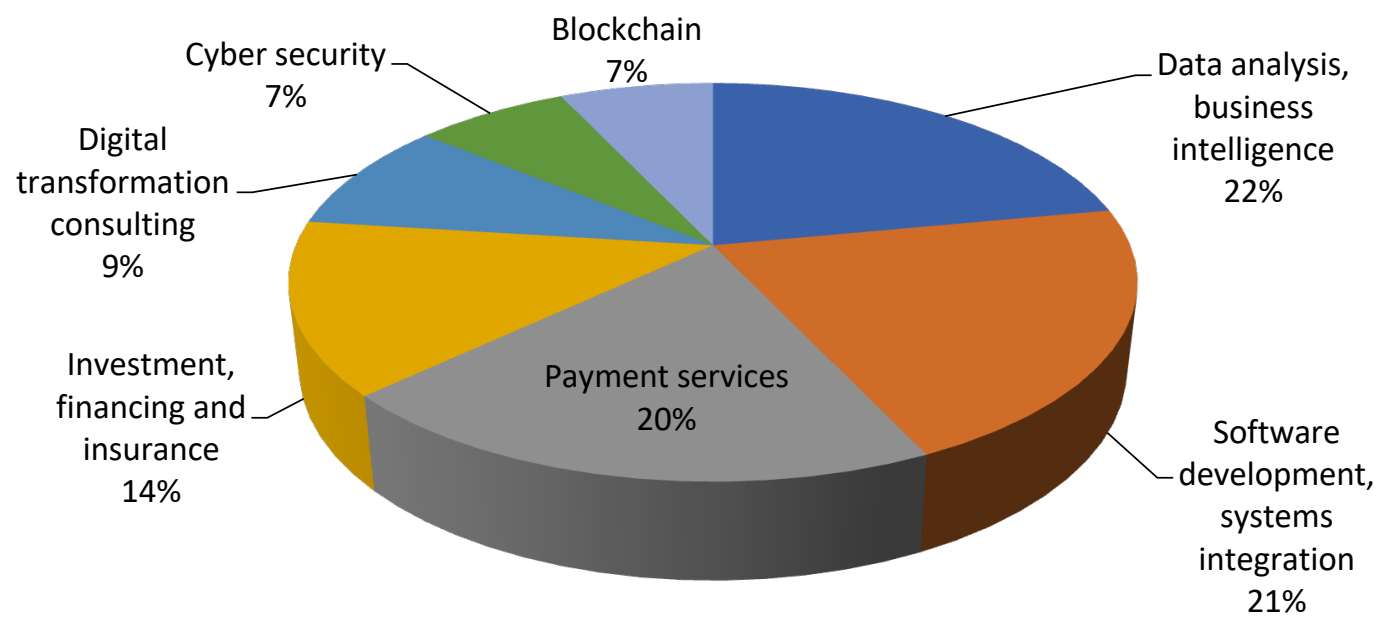

Sources: $M N B, N A V$ 
Cooperation between banks and FinTech companies is still at a fairly early stage in the Hungarian sector. There are serious difficulties in cooperating, the most significant of which are:

- the two types of organizations are characterized by very different corporate cultures, which can be traced mainly to traditions.

- size differences (FinTech is usually a startup with a CEO who multi functionally plays several different roles in the company)

- banks have a hierarchical operation, in most cases, FinTech does not have formalized roles

- a FinTech can respond quickly to emerging needs, be able to improvise (there are no such strict regulations at either the process or IT level as at a bank)

- for a bank, all processes are regulated and controlled

- project management: every bank has an existing project technology that is difficult for a FinTech company to join (Tóth, 2019)

Also, the vast majority of Hungarian banks are characterized by outdated IT core systems, which make it difficult to integrate new, external solutions. Furthermore, the current economic uncertainty may be an obstacle to closer attempts at cooperation, as FinTech companies have no crisis management experience and are facing this type of problem for the first time. The lack of routine in management and a stable financial background makes banks insecure in terms of longer-term forms of cooperation.

\section{Future trends}

Based on the information obtained during the research, in my opinion, the cooperation between banks and FinTech will be even greater shortly. Banks have already recognized the potential of new entrants, and the need for cooperation is not an issue. However, due to the uncertainty caused by the economic situation, these strategies are more about the short-term, targeted for concrete solutions. Instead of long, deep strategic partnerships, the outsourcing of individual sub-tasks or an association with specific projects will be typical. Acquisitions by banks have not been typical solutions in the domestic FinTech sector so far, and there will be no significant change in the coming years. Although we find exciting examples of venture capital investing, the uncertainty of the next 1-2 years is not conducive to investor sentiment.

One of the most positive developments for banks in 2020 is that the online management of any kind of finance is becoming more widespread in Hungary, and in recent years, due to the situation, this has accelerated. As for Danóczy and Sajtos (2020), consumer groups, 
appear in the online banking space who have rigidly rejected this, such as a significant portion of the over-60s. This brought the two most distant groups, retired aged and Generation Z, closer together in terms of consumer behavior. Downsizing of the branch network will sooner or later become inevitable, and currently, a bank branch has fewer and fewer features that cannot be started through an online channel or even a smart ATM. In the long run, this process may also accelerate. However, it is feared that most banks will further delay the replacement of basic IT systems, as they have done in previous years. This can lead to additional complications in integrating new solutions and the reliability of services. Last but not least, banks need to respond to the emergence and growing share of BigTech companies in the Hungarian market, which have huge capital compared to FinTech companies and greater social acceptance.

\section{Conclusion}

The most important question this year is how the processes affecting the core banking activities, such as the ratio of non-performing loans, changes in deposits, and exchange rate policy, will develop. For FinTechs, the key issue is crisis management and building long-term stability. Companies have so far struggled with mistrust and reservations stemming from the state of domestic financial culture. Overall, it can be stated that the Hungarian banking sector currently has a good chance to catch up and work on their disadvantages compared to the region in terms of digital maturity. Although the situation is too complex, there are many variables to say for sure, but in my opinion, the COVID19 epidemic, in addition to its numerous negative social and economic effects, can bring about positive changes in the domestic credit institution sector. For sure, in the coming quarters, it will be worthwhile to follow the intensity of the processes taking place in the sector. There will be some players who will handle new situations very well, the question is whether this will bring significant change at the industry level. 


\section{References}

Baker, T., \& Judge, K. (2020). How to Help Small Businesses Survive COVID-19. Columbia Law and Economics Working Paper, (620).

Deloitte. (2018). Digital Banking Maturity Study EMEA.

https://www2.deloitte.com/hu/en/pages/financial-services/articles/digital-banking-maturityemea.html

Danóczy, B., \& Sajtos, P. (2020). FinTech-ek górcsố alatt: Merre tart a hazai FinTech szektor?. MNB. https://www.mnb.hu/letoltes/danoczy-balint-sajtos-peter-fintech-ek-helyzetemagyarorszagon.pdf

El-Erian, M. A. (2020, March 17). The Coming Coronavirus Recession And the Uncharted Territory Beyond. Foreign Affairs. https://www.foreignaffairs.com/articles/2020-0317/coming-coronavirus-recession

Elliott, L. (2020, March 15). Prepare for the coronavirus global recession. The Guardian. https://www.theguardian.com/business/2020/mar/15/prepare-for-the-coronavirus-global-recession

Ghosh, I. (2020, September 22). This is how the global economy will recover from COVID-19, according to CEOs. World Economic Forum. https://www.weforum.org/agenda/2020/09/covid19-recovery-shape-economy-ceo/

Kerényi, Á., Molnár, J., \& Müller, J. (2018). Veszedelmes viszonyok a bankok és a fintechek között? Gazdaság és Pénzügy, 5(1), 88-99. ISSN 2415-8909

Mills, K., \& McCarthy, B. (2017, April 26). How Banks Can Compete Against an Army of Fintech Startups. Harvard Business Review. https:/hbr.org/2017/04/how-banks-cancompete-against-an-army-of-fintech-startups

MNB. (2020, April). FinTech és digitalizációs jelentés, 2020 április. https://www.mnb.hu/letoltes/fintech-es-digitalizacios-jelente-s-final.pdf

MNB. (2020, November). Pénzügyi stabilitási jelentés, 2020 november. https://www.mnb.hu/letoltes/penzugyi-stabilitasi-jelentes-2020-november.pdf

Tóth, T. (2019). A digitalizáció hatása a magyar bankszektorra, és banki stratégiák a digitális transzformáció tükrében (12616) [Master's thesis, Corvinus University of Budapest]. Corvinus Theses and Outstanding Student Papers. 